OPEN ACCESS

Edited by:

Lawrence Jun Zhang,

University of Auckland, New Zealand

Reviewed by:

Andrew Chiou,

Central Queensland University,

Australia

Heping Wu,

Northwest Normal University, China

*Correspondence: Rohaya Binti Abdullah

rohayamfda@usm.my

Specialty section:

This article was submitted to Educational Psychology, a section of the journal

Frontiers in Psychology

Received: 22 November 2021

Accepted: 09 February 2022

Published: 03 March 2022

Citation:

Chen F and Abdullah RB (2022)

Teacher Cognition and Practice of

Educational Equity in English as a

Foreign Language Teaching.

Front. Psychol. 13:820042.

doi: 10.3389/fpsyg.2022.820042

\section{Teacher Cognition and Practice of Educational Equity in English as a Foreign Language Teaching}

\author{
Feifei Chen ${ }^{1,2}$ and Rohaya Binti Abdullah ${ }^{2 *}$ \\ ${ }^{1}$ Department of College English, Zhejiang Yuexiu University, Shaoxing, China, ${ }^{2}$ School of Educational Studies, Universiti Sains \\ Malaysia, Penang, Malaysia
}

Teachers involved in English as a foreign language (EFL) teaching play a significant role in the process of moving toward educational equity. Teacher cognition is very influential in shaping teacher practice and thus affects students' academic performance. However, although the role of EFL teachers as equity agents has been recognized, few studies have explored EFL teachers in-depth in terms of their cognition and practice. Moreover, no review studies have given sufficient attention to the task of elucidating the interrelations between EFL teachers' cognition and practices in the context of educational equity. Therefore, to provide a novel perspective and generate fresh insights into this research field, the current study attempts to explain the connotations of these constructs, highlights the interplay between EFL teachers' equity-oriented cognition and practice, and identifies both experiential and contextual factors that might have an effect throughout the teaching process. Finally, practical implications and directions for teachers, researchers, policymakers, and social justice leaders who are interested in actualizing education as a means of attaining equity are also discussed.

Keywords: English as a foreign language teaching, educational equity, teacher cognition, teacher practice, interrelations, factors

\section{INTRODUCTION}

Educational equity, a mandate from Sustainable Development Goal 4 (SDG 4), has long been considered to be an "important factor in enrichment of quality in education" (Borazjani and Bagheri, 2016, p. 61). Learning English as a foreign language (EFL) is established as a compulsory duty in many non-English-speaking countries and is viewed as an essential skill for global competence (Villegas, 2017). Therefore, under the backdrops of moving toward equitable education, EFL teaching is closely related to educational equity and exerts a significant influence on the process of minimizing educational and social gaps around the globe. Equity in EFL teaching can be promoted by ensuring equal opportunities for every learner (Lachance et al., 2019) and responding to the educational needs of diverse student populations (Leiva et al., 2021). However, inequities in EFL teaching persist and primarily manifest in teachers' domination over the class without leaving students equal opportunities to become engaged in the teaching process (Chen and Vibulphol, 2019; Wu, 2019) and in the failure to understand learners' needs by merely adopting a one-size-fits-all approach regardless of students' identity markers 
(Du and Guan, 2016; Khdar et al., 2019), which may lead to low self-efficacy among students and discouraging learning outcomes (Mo, 2020).

Considerable attention has been given to equity issues occurring in the EFL teaching context; however, the majority of relevant research has been conducted from a macro perspective employing quantitative methods, debating the educational inequities triggered by factors such as disadvantaged learners' gender (Meshkat and Nejati, 2017; Ariyanto, 2018; Brutt-Griffler and Kim, 2018), race (Von Esch et al., 2020; Xiang and YenikaAgbaw, 2021), and socioeconomic status (Lee, 2020; Lorenzo et al., 2020; Yao, 2021). In contrast, limited attention has been given to the role of a subtle yet critical link-EFL teachers, who play a pivotal role in maintaining a fair and inclusive education for all learners.

The interplay between EFL teacher cognition and teacher practice has been noted (Wang and Ryan, 2020). Research has supported the claim that EFL teachers' cognition can be very influential in shaping their instructional practices, thereby affecting the learning outcomes of students (Kang and Cheng, 2014; Mohammadi and Moradi, 2017; Gao et al., 2020). Accordingly, teachers' equitable practices under the guidance of their equity-oriented cognition can keep learners "intellectually, socially, and psychologically engaged” (Schreiner, 2014, p.10). Given the importance that teacher cognition and practice have for creating an equitable and harmonious learning atmosphere, teachers who undertake the task of EFL teaching should act as equity agents to help each individual achieve his or her full potential (Guo et al., 2019).

Despite the fundamental role that teachers play in promoting educational equity in EFL teaching, only a few studies have investigated the association between teacher cognition and practice from an equity perspective. Furthermore, hitherto, there have been no review studies aimed at investigating these constructs and shedding light on the inner association between them. As Fullan (2001) argued, the success of educational reforms depends on teachers' thoughts and actions. In line with this claim, the present study seeks to address this gap by constructing transformative visions for educational equity and elucidating the interrelationships between teacher cognition and practice that are pertinent to educational equity in EFL settings. More specifically, the study presents research findings that identify the factors influencing teachers' equityoriented cognition and practice, which may help researchers develop investigational instruments to conduct in-depth studies.

\section{DEFINITION OF EDUCATIONAL EQUITY}

The concept of educational equity has attracted much attention in recent years (Scheurich et al., 2017). To attain a correct understanding of this notion, the keyword "equity" should first be clarified. However, in some sense, the word "equity" is often interpreted in a confusing and problematic way, being used interchangeably with the words "equality" and "justice" (Panthi et al., 2018; Rasooli et al., 2019; Shaeffer, 2019), and these latter two terms are also closely related (Robeyns, 2009). These concepts, although they overlap in certain dimensions, are distinct in the context of educational goals and purposes. Specifically, "equity" focuses more on obtaining what the learner needs to achieve success (Minow, 2021), indicating objective assessments and subjective morals, while "equality" mainly refers to receiving the same treatment and resources and has normative overtones (Smith et al., 2017). Both "equity" and "equality" aim to ensure "justice," which emphasizes the "demands for equal rights under the law" (Stoll, 2011, p. 36). To illustrate this overlapping terminology, a Boolean diagram is provided (Figure 1).

Inspired by Coleman et al. (1966), who proposed establishing equality of educational opportunities to address equity issues, several researchers, such as Gipps and Stobart (2009), Klenowski (2009), and McLaughlin (2010), have made similar claims that a situation in which equal educational opportunity is granted to everyone constitutes the essence of "educational equity." Similarly, Blankstein et al. (2016, p. 3) defined that term as a "commitment to ensure that every student receives what he or she needs to succeed academically." There is consensus among scholars that the term educational equity, which has richer implications (Barrow and Grant, 2019), depicts a situation in which each individual, irrespective of race, gender, family background, or any other personal marker, can be endowed with an equal opportunity to fulfill his or her academic potential (McLaughlin, 2010).

Based on a widely accepted explanation, the term contains two levels of meanings, "fairness" with respect to "achieving the educational potential" and "inclusion" with regard to "ensuring a basic minimum standard of education for all” (OECD, 2008, p. 2). As such, educational equity serves as both a means and an end, a principle and an ideal, a process and an outcome, and it requires teachers, educators, and policy-makers to make

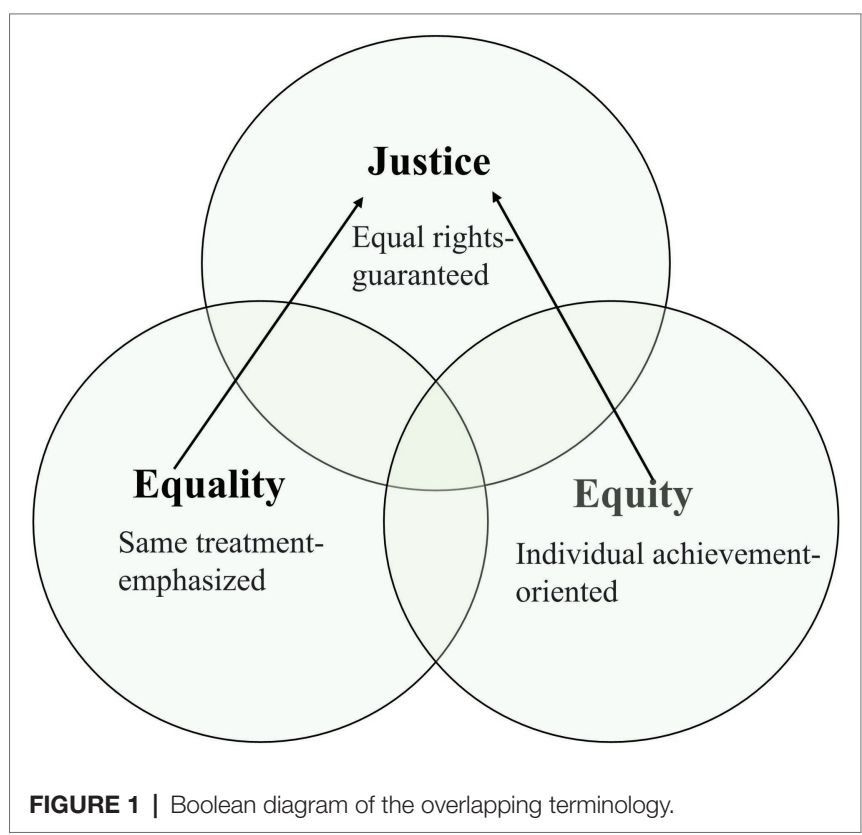


joint efforts to minimize students' academic gaps to allow them to realize their potential. As Campbell (2020, p. 17) noted, narrowly defining equity in terms of outcome performance may keep people from truly understanding "the wider contexts, processes and outcomes of inequity." Therefore, a proper interpretation of educational equity that outlines the need for an equal chance at academic success can help solve the conceptual dilemma and thus further promote justice within the educational context.

\section{TEACHER COGNITION REGARDING EQUITY}

Teacher cognition, which is initially shaped by a teacher's schooling and professional experiences, refers to cognitive constructs such as knowledge, beliefs, and thoughts (Borg, 2003, 2013). Considering the tremendous impact of teacher cognition on practices, some researchers have attempted to clarify the nature of teachers' equity-oriented cognition (Dweck, 2010; Ramaley, 2014; Schreiner, 2014; Brinegar et al., 2018; Skerrett et al., 2018; Nadelson et al., 2019; Stembridge, 2019). Dweck (2010) stated that teachers who are focused on equity should not only claim to have faith in their students' abilities to learn but also show a commitment to the task of finding a way to facilitate such learning. Inspired by Dweck, Ramaley (2014) highlighted the importance of equity-oriented cognition for teachers to reflect on what is needed to help students feel a sense of belonging and on other factors that can help meet the linguistic and sociocultural needs of students from different backgrounds. His view is expressed by the statement that equity-focused teachers expect to "empower each student to transform themselves" (Brinegar et al., 2018, p. 2). However, these studies failed to explicitly describe the nature of equityoriented cognition.

Later, Nadelson et al. (2019) further elaborated on the concept by using quantitative and qualitative approaches. Apart from student-centered learning, informal leadership, advocacy for equity needs, and culturally responsive teaching were also identified as integral components of teachers' equity mindsets. In accordance with the arguments made by Gay (2000), teachers should be culturally conscious and sustaining to create an impartial and inclusive learning atmosphere. The study was innovative in that it crystalized the six attributes of teachers' equity cognition; however, its findings were limited to a small number of cases. As a result, a model of teachers' equityoriented cognition that can facilitate teaching must be validated and developed by further research.

The importance of equipping EFL teachers with equityoriented cognition in a multicultural society cannot be overemphasized. As Lucas and Schecter (1992) noted, to teach toward equity, teachers must become aware of students' sociocultural diversity and introspective regarding their own values, beliefs, and identities within the whole educational process, and then, they must incorporate these elements into their teaching. Indeed, recognizing the vital links between EFL teachers' cognition and practices is a first step to preparing teachers for inclusive and effective teaching.

\section{TEACHER PRACTICE OF EQUITY}

Teacher practice, as noted by Woods (1996), is the application or employment of teachers' knowledge, beliefs, and thoughts in classroom teaching. Under the global discourses of neoliberalism, an increasing number of studies aiming to illuminate English teachers' equitable practices have emerged. Banks (1995, p. 152) defined equity pedagogy as teaching strategies and classroom environments that can help even disadvantaged and marginalized students to become "reflective and active citizens of a democratic society." To that end, teachers should be interest-driven and student-centered, prioritizing students' linguistic and sociocultural needs, offering them equal learning resources and opportunities, and advocating group communication and collaboration so that every student can be engaged in a fair and just learning environment (Gay, 2013; Januszyk et al., 2016). By revisioning and reenacting contemplative equity pedagogy from a humanity lens, Powietrzynska et al. (2021) advocated for building rational trust and authentic relationships between teachers and students to embrace equity.

To give an example of equitable pedagogical practice, Dyches and Sams (2018, p. 373), who perceived the context-bound "pedagogical idealism" of teachers as "an orientation to teaching that aspires to equity and justice for all students," exemplified a realist approach that combined equitable teaching with traditional materials. In addition, certain equity frameworks, such as culturally relevant pedagogy (Ladson-Billings, 1995), culturally responsive teaching (Gay, 2000), and equity literacy (Gorski, 2017), can also provide practical strategies to sustain an inclusive and just learning atmosphere for culturally and linguistically diverse students in an era of standards-based and teacher-dominated teaching.

Likewise, the importance of promoting equitable teaching among EFL teachers is self-evident. Without explicit teaching methods to guide teachers' practices toward fairness and inclusion, teachers will inevitably exhibit bias toward learners at different levels (Staats et al., 2016). Educational equity, as noted by Dyches and Boyd (2017, p. 12), should "pulsate throughout every instructional maneuver." Therefore, to create a fair learning environment for all, ongoing studies are needed to construct a clear picture of equitable pedagogy among EFL teachers.

\section{INTERRELATIONS AMONG EDUCATIONAL EQUITY, EFL TEACHERS' COGNITION, AND PRACTICES}

The increase in the number of English language learners worldwide has made (in) equity in the English teaching context a critical issue that must be properly addressed (Murray, 2020). Conceivably, the focus on research concerning educational 
equity has shifted from the macro-level of fair access to education for all to the micro-level that mandates that everyone receive what they need to fulfill their learning potential. Under such a transformative context, the active forces-teachers-stand at the heart of ensuring fairness and justice in the educational process (Crawford-Garrett, 2017). Thus, to build a more "democratic, participatory, equitable, professional, and egalitarian future" for English language teaching (Yazan and Rudolph, 2018, p. 6), EFL teachers should have correct cognitions regarding equity and should engage in relevant equitable pedagogy in actual classrooms.

EFL teachers' instructional practices have been shown to be influenced by their implicit and intricate cognition (Borg, 2003; López-Barrios et al., 2021). When teachers provide instruction in the context of actual classroom teaching, apart from being influenced by contextual factors in and outside the classroom, they are also subject to their cognitive constructs, such as knowledge, beliefs, and thoughts. In Borg's framework (Borg, 2003), three elements, namely, teacher cognition, teacher practice, and contextual factors, dynamically interact with each other throughout the teaching process.

Taken together, to provide education for all, EFL teachers should articulate the importance of equal opportunities for each learner and, in the meantime, show great commitment to the task of facilitating such opportunities (Guo et al., 2019). In simple terms, EFL teachers should be equipped with equity-conscious cognition as part of their mindsets when engaging in instructional practices. Only when equity gaps are borne in mind can teachers successfully ameliorate the educational inequities embedded in their instructions (Orfield, 2014). Based on the above discussion and Borg's language teacher framework, a framework that can highlight the interrelations among the constructs of educational equity, EFL teachers' cognition, and practices is proposed (Figure 2).

\section{EMPIRICAL STUDIES CONCERNING THE INTERRELATION BETWEEN EQUITY-RELATED TEACHER COGNITION AND PRACTICE}

Although teacher cognition and practices have been a recurring theme in the EFL context, only a few researchers have attempted to investigate the interrelations between teachers' cognition and practice that are pertinent to educational equity. A small-scale case study by Posti-Ahokas and Janhonen-Abruquah (2021) reported that equity-centered practices could only occur if teachers were aware of the causes of inequities and the impact of inequities on teacher positionality. That is, teachers' equitybound cognition is a prerequisite that can guarantee equitable practices. In contrast to this statement, a growing body of studies (Chen and Vibulphol, 2019; Wei and Cao, 2020; Irgin, 2021; Wu et al., 2021) has found a distinctive mismatch between EFL teachers' cognition and practices; this dissonance is also reflected in teachers' cognitions and practices toward equity (Erling et al., 2021).

Notably, the mismatch in question here, which has become quite serious, lies in the fact that although teachers report that they have adopted a student-centered stance, they act in precisely the opposite way during their teaching. In an empirical qualitative study investigating four Chinese EFL teachers' instructional decision making, the findings showed that although teachers intended to build an active and fair environment for all, their actual teaching was still teacher-centered rather than

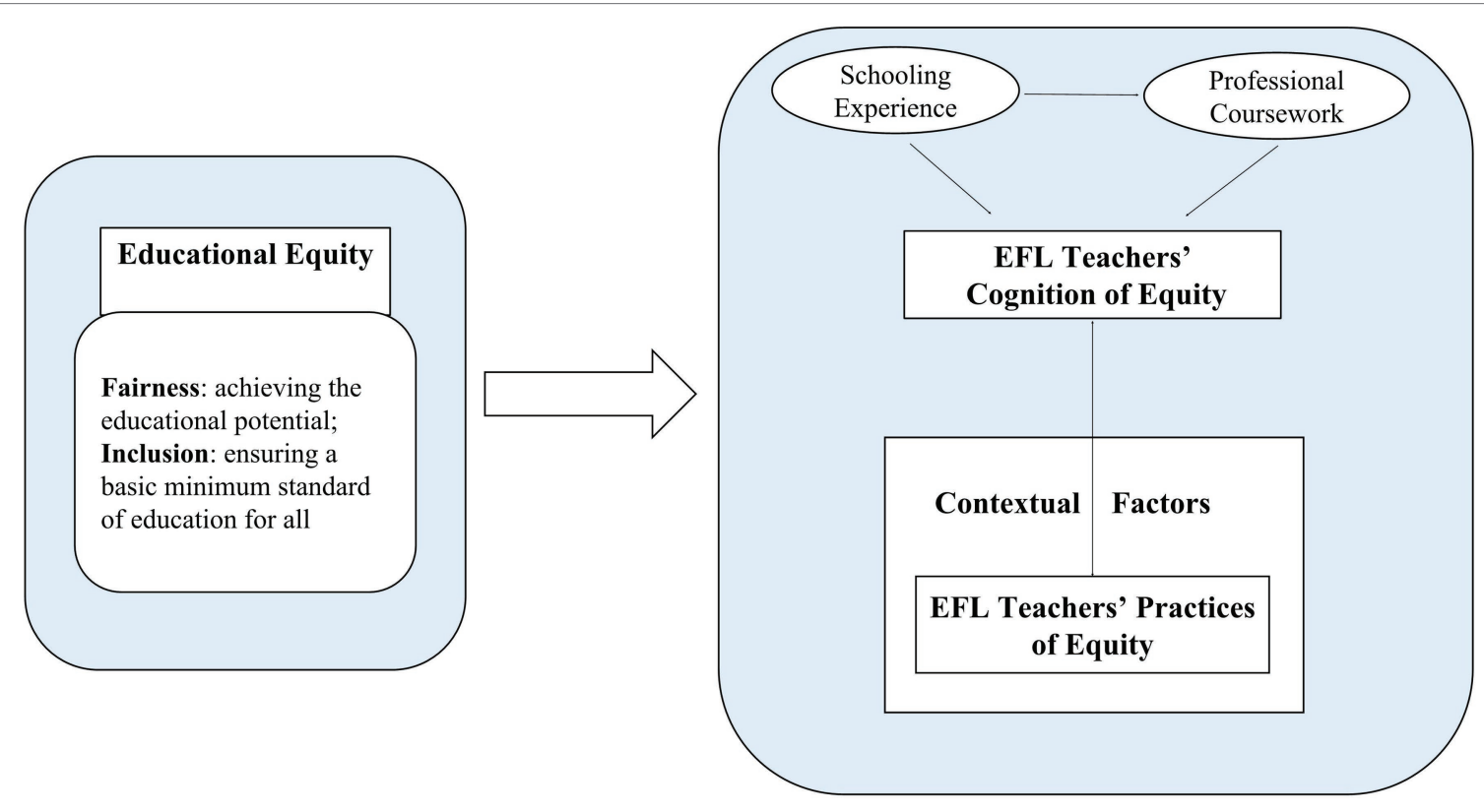

FIGURE 2 | Interrelationship among educational equity, EFL teacher's cognition, and practices (adapted from Borg, 2003; OECD, 2008). 
equity-oriented (Zhang and Yang, 2017). In a similar vein, the findings of one mixed study showed that although EFL teachers self-reported that they recognized equity as one of the most fundamental guidelines to achieve social justice when interacting with students in the classroom, they were subject to strong biases in terms of students' genders, personalities, social backgrounds, and English-speaking abilities (Chen, 2020). Previous studies have revealed that although EFL teachers selfreport being aware of equity, their practices are still far from satisfactory (Maeng and Lee, 2015).

Certain key experiential and contextual factors have been reported to account for the hidden mechanism that triggers the incongruence between EFL teachers' equity-related cognition and practice. Drawing on the framework of Borg (2003), experiential factors are mainly associated with teachers' learning and professional experiences that shape their initial cognition of teaching. Using a qualitative approach to explore two Indonesian EFL teachers' cognition concerning the incorporation of equity into their teaching, Sulistyowardani et al. (2020) revealed that teachers' own learning experiences and personal beliefs were major factors shaping teachers' cognition regarding justice and thus affected their practices. The findings are consistent with those of Kaur (2012, p. 487), who maintained teachers' former experiences, beliefs, and perspectives could "re-inscribe stereotypes and perpetuate the social and historical inequities." Regarding contextual factors, evidence has suggested that curriculum demand can transform EFL teachers' cognition toward equity (Sulistyowardani et al., 2020). Moreover, researchers (Wang and Gao, 2013; Grudnoff et al., 2017) identified that the reason teachers often fail to realize the importance of equity is the inadequacy of teacher education programs concerning equity and justice. Especially in China, EFL teachers who are deeply influenced by Confucianism (Sun and Zhang, 2021), the dominant philosophical paradigm that asserts teachers' authority over students (Gao, 2020), and utilitarian examoriented doctrines by which students' scores matter most (Liu et al., 2019; Mo, 2020) may somehow demonstrate a disjuncture between equity-ended cognitions and practices.

\section{IMPLICATIONS AND DIRECTIONS FOR FUTURE STUDIES}

To conclude, the main goal of the current study was to generate fresh insights for any parties concerned with the research field of EFL teachers' cognition and practice regarding equity. The three constructs, namely, educational equity, EFL teachers'

\section{REFERENCES}

Andrews, D. J., Carter, G. R., and Stroupe, D. (2017). Teacher education and teaching in the present political landscape: promoting educational equity through critical inquiry and research. J. Teach. Educ. 68, 121-124. doi: 10.1177/0022487117691243

Ariyanto, S. (2018). A portrait of gender bias in the prescribed Indonesian ELT textbook for junior high school students. Sex .Cult. 22, 1054-1076. doi: 10.1007/s12119-018-9512-8 cognition, and practices of equity, were explained in detail. Moreover, the intricate connection between EFL teachers' cognition and practices pertinent to educational equity was also illuminated with the support of theoretical and empirical evidence. From the literature reviewed, it can be inferred that within an educational context characterized by inequities and injustices, there is often a mismatch between EFL teachers' claimed cognitions and actual classroom practices regarding educational equity. Factors that cause such a mismatch can be both experiential (referring to teachers' learning and professional experiences) and contextual (including curriculum demand, teacher education programs, teacher authority, and exam-oriented doctrines). However, facilitating factors seem to have been investigated only narrowly and deserve further exploration.

These findings can be thought provoking for EFL teachers who are involved in the global educational system to reflect on their pedagogical thoughts and deeds. Given the crucial role teachers play in dismantling inequities that hinder students' development and in closing the academic gap, it is a good sign that equity, as a common concern in the English language teaching area (Erling et al., 2020), has become a long-term pursuit for EFL teachers with equitable visions both at home and abroad. Furthermore, since equity is perceived as an important predictor of students' self-efficacy (Daemi et al., 2017), this study has important implications for educational experts and policy-makers concerning how to include more voices from culturally and linguistically diverse students and how to verify whether teachers are incorporating equity into their classroom practices (Riordan et al., 2019). As claimed by Andrews et al. (2017), inequity will be amplified in schools if poorly qualified teachers continue to teach the most disadvantaged students. Therefore, to make instructional equity a reality, researchers or social justice leaders who are interested in actualizing education as a means of promoting equity should continue to explore the facilitating factors that constitute English teachers' equity-focused cognitions and practices by using qualitative methods in longitudinal studies.

\section{AUTHOR CONTRIBUTIONS}

FC read through the relevant literature and shed light on the definition and connection between teacher cognition and practices. RA provided insightful suggestions. All authors contributed to the article and approved the submitted version.
Banks, J. A. (1995). Equity pedagogy: An essential component of multicultural education. Theory Pract. 34, 152-158. doi: $10.1080 / 00405849509543674$

Barrow, M., and Grant, B. (2019). The uneasy place of equity in higher education: tracing its (in)significance in academic promotions. High. Educ. 78, 133-147. doi: 10.1007/s10734-018-0334-2

Blankstein, A. M., Noguera, P. O, and Kelly, L. (2016). Excellence through Equity: Five Principles of Courageous Leadership to Guide Achievement for Every Student. Washington, DC: ASCD. 
Borazjani, Z., and Bagheri, M. S. (2016). Strengths and weaknesses of educational equity in English language teaching at Iranian and Finnish primary and secondary schools. J. Stu. Learn. 5, 55-75.

Borg, S. (2003). Teacher cognition in language teaching: A review of research on what language teachers think, know, believe, and do. Lang. Teach. 36, 81-109. doi: 10.1017/S0261444803001903

Borg, S. (2013). Teacher Research in Language Teaching: A Critical Analysis. United States: Cambridge University Press.

Brinegar, K., Harrison, L., and Hurd, E. (2018). Becoming transformative, equity-based educators. Middle Sch. J. 49, 2-3. doi: 10.1080/00940771.2018.1524253

Brutt-Griffler, J., and Kim, S. (2018). In their own voices: development of English as a gender-neutral language. Eng. Today 34, 12-19. doi: 10.1017/ S0266078417000372

Campbell, C. (2020). Educational equity in Canada: The case of Ontario's strategies and actions to advance excellence and equity for students. Sch. Leader. Manage. 41, 409-428. doi: 10.1080/13632434.2019.1709165

Chen, F. (2020). An empirical study of teacher-student interaction in college English classroom from the perspective of educational equality. Rev. Cercetare Int. Soc. 71, 41-58. doi: 10.33788/rcis.71.3

Chen, X., and Vibulphol, J. (2019). An exploration of motivational strategies and factors That affect strategies: A case of Chinese EFL teachers. Int. Educ. Stud. 12, 47-58. doi: 10.5539/ies.v12n11p47

Coleman, J. S., Campbell, E. Q., Hobson, C. J., McPartland, F., Mood, A. M., Weinfeld, G. D., et al. (1966). Equality of Educational Opportunity. (United States: Government Printing Office).

Crawford-Garrett, K. (2017). 'The problem is bigger than us': grappling with educational inequity in TeachFirst New Zealand. Teach. Teach. Educ. 68, 91-98. doi: 10.1016/j.tate.2017.08.010

Daemi, N., Masoumeh, A. T., and Zafarghandi, A. M. (2017). The relationship between classroom environment and EFL learners' academic self-efficacy. Int. J. Edu. Lit. Stu. 5, 16-23. doi: 10.7575/aiac.ijels.v.5n.4p.16

$\mathrm{Du}, \mathrm{H}$., and Guan, H. (2016). Hindrances to the new teaching goals of college English in China. Eng. Today 32, 12-17. doi: 10.1017/ S0266078415000462

Dweck, C. S. (2010). Mind-sets and equitable education. Princ. Leadersh. 10, 26-29.

Dyches, J., and Boyd, A. (2017). Foregrounding equity in teacher education: Toward a model of social justice pedagogical and content knowledge. J. Teach. Educ. 68, 476-490. doi: 10.1177/0022487117705097

Dyches, J., and Sams, B. L. (2018). Reconciling competing missions of English education: A story of pedagogical realism. Chang. Eng. Stu. Culture Edu. 25, 370-383. doi: 10.1080/1358684X.2018.1499006

Erling, E. J., Foltz, A., and Wiener, M. (2021). Differences in English Teachers'beliefs and practices and inequity in Austrian English language education: could Plurilingual pedagogies help close the gap? Int. J. Multilingual. 18, 570-585. doi: 10.1080/14790718.2021.1913170

Erling, E. J., Radinger, S., and Foltz, A. (2020). Understanding low outcomes in English language education in Austrian middle schools: The role of Teachers' beliefs and practices. J. Multiling. Multicult. Dev. 7, 1-17. doi: 10.1080/01434632.2020.1829630

Fullan, M. (2001). The New Meaning of Educational Change. 3rd Edn. United States: Routledge.

Gao, H. B. (2020). "Confucianism," in Rituals and Practices in World Religions. eds. D. Yaden, Y. Zhao, K. Peng and A. Newberg (Germany: Springer), 88-98.

Gao, L. X., Zhang, L. J., and Tesar, M. (2020). Teacher cognition about sources of english as a foreign language (efl) listening anxiety: a qualitative study. Ling. Philos. Invest. 19, 64-85. doi: 10.22381/LPI1920203

Gay, G. (2000). Culturally Responsive Teaching: Theory, Research, and Practice. United States: Teachers College Press.

Gay, G. (2013). Teaching to and through cultural diversity. Curric. Inq. 43, 48-70. doi: 10.1111/curi.12002

Gipps, C., and Stobart, G. (2009). "Fairness in assessment," in Educational Assessment in the 21st Century. eds. E. C. Wyatt-Smith and J. Cumming (Netherlands: Springer), 105-118.

Gorski, P. C. (2017). Reaching and Teaching Students in Poverty: Strategies for Erasing the Opportunity Gap. United States: Teachers College Press.

Grudnoff, L., Haigh, M., Hill, M., Cochran-Smith, M., Ell, F., and Ludlow, L. (2017). Teaching for equity: insights from international evidence with implications for a teacher education curriculum. Curric. J. 28, 305-326. doi: 10.1080/09585176.2017.1292934

Guo, Q., Tao, J., and Gao, X. (2019). Language teacher education in system. System 82, 132-139. doi: 10.1016/j.system.2019.04.001

Irgin, P. (2021). "Exploring teachers' beliefs about listening in a foreign language," in Exploring Teachers' Beliefs about Listening in a Foreign Language. ed. V. Turel (Australia: IGI Global), 199-220.

Januszyk, R., Miller, E. C., and Lee, O. (2016). Addressing student diversity and equity: the "next generation science standards" are leading a new wave of reform. Sci. Child. 53, 28-31.

Kang, Y., and Cheng, X. (2014). Teacher learning in the workplace: A study of the relationship between a novice EFL Teacher's classroom practices and cognition development. Lang. Teach. Res. 18, 169-186. doi: 10.1177/1362168813505939

Kaur, B. (2012). Equity and social justice in teaching and teacher education. Teach. Teach. Edu. 28, 485-492. doi: 10.1016/j.tate.2012.01.012

Khdar, A. E. L., Rguibi, S., and Bouziane, A. (2019). The need for educational equity through multimethodology and differentiation in the Moroccan EFL classroom. Stu. Ang. Res. 16, 33-47. doi: 10.15584/sar.2019.16.3

Klenowski, V. (2009). Australian indigenous students: addressing equity issues in assessment. Teach. Educ. 20, 77-93. doi: 10.1080/ 10476210802681741

Lachance, J. R., Honigsfeld, A., and Harrell, G. (2019). Equal educational opportunity for English learners: ESL teachers' conceptualizations on the importance of academic language. TESOL J. 10:e00415. doi: 10.1002/tesj.415

Ladson-Billings, G. (1995). Toward a theory of culturally relevant pedagogy. Am. Educ. Res. J. 32, 465-491. doi: 10.3102/00028312032003465

Lee, C. (2020). Hidden ideologies in elite English education in South Korea. J. Multiling. Multicult. Dev. 42, 221-233. doi: 10.1080/01434632.2020.1865383

Leiva, L. R., Miranda, L. P., and Riquelme-Sanderson, M. (2021). Social justice in the preparation of English language teachers. Mextesol J. 45, 1-14.

Liu, D., Xue, S., and Rong, H. (2019). A preliminary study on challenges and solutions for college EFL education in ethnic minority regions of China. Engl. Lang. Teach. 12:15. doi: 10.5539/elt.v12n3p15

López-Barrios, M., Martín, M. G. S., and Debat, E. V. (2021). EFL vocabulary teaching beliefs and practices: The case of two teachers in Argentina. TESOL J. 12, 1-17. doi: 10.1002/tesj.533

Lorenzo, F., Granados, A., and Rico, N. (2020). Equity in bilingual education: socioeconomic status and content and language integrated learning in monolingual southern Europe. Appl. Ling. 42, 393-413. doi: 10.1093/applin/ amaa037

Lucas, T., and Schecter, S. R. (1992). Literacy education and diversity: Toward equity in the teaching of Reading and writing. Urban Rev. 24, 85-104. doi: 10.1007/BF01239354

Maeng, U., and Lee, S. M. (2015). EFL teachers' behavior of using motivational strategies: The case of teaching in the Korean context. Teach. Teach. Educ. 46, 25-36. doi: 10.1016/j.tate.2014.10.010

McLaughlin, M. J. (2010). Evolving interpretations of educational equity and students With disabilities. Except. Child. 76, 265-278. doi: $10.1177 / 001440291007600302$

Meshkat, M., and Nejati, R. (2017). Does emotional intelligence depend on gender? A study on undergraduate English majors of three Iranian universities. SAGE Open 7:215824401772579. doi: 10.1177/2158244017725796

Minow, M. (2021). Equality vs equity. Am. J. Law. Eq. 1, 167-193. doi: 10.1162/ ajle_a_00019

Mo, X. (2020). Teaching Reading and Teacher Beliefs: A Sociocultural Perspective. Netherlands: Springer.

Mohammadi, M., and Moradi, K. (2017). Exploring change in EFL teachers' perceptions of professional development. J. Teach. Edu. Sustain. 19, 22-42. doi: $10.1515 /$ jtes-2017-0002

Murray, D. E. (2020). The world of English language teaching: creating equity or inequity? Lang. Teach. Res. 24, 60-70. doi: 10.1177/1362168818777529

Nadelson, L. S., Miller, R. G., Helen, H., Bang, N. M., and Walthall, B. (2019). Is equity on their mind? Documenting teachers' education equity mindset. World J. Edu. 9, 26-40. doi: 10.5430/wje.v9n5p26

OECD (2008). Policy Brief: Ten Steps to Equity in Education. Available at: http://www.oecd.org/education/school/39989494.pdf (Accessed January 21, 2022).

Orfield, G. (2014). Tenth annual Brown lecture in education research: A new civil rights agenda for American education. Educ. Res. 43, 273-292. doi: $10.3102 / 0013189$ X14547874 
Panthi, R. K., Luitel, B. C., and Belbase, S. (2018). Teachers' perception of social justice in mathematics classrooms. J. Res. Math. Educ. 7:7. doi: 10.17583/ redimat.2018.2707

Posti-Ahokas, H., and Janhonen-Abruquah, H. (2021). Towards equity literacy: exploratory enquiry with Finnish student teachers. Eur. J. Teach. Educ., 1-18. doi: 10.1080/02619768.2021.1952977

Powietrzynska, M., Noble, L., O'Loughlin-Boncamper, S., and Azeez, A. (2021). Holding space for uncertainty and vulnerability: reclaiming humanity in teacher education through contemplative equity pedagogy. Cult. Stud. Sci. Educ. 16, 951-964. doi: 10.1007/s11422-021-10035-x

Ramaley, J. (2014). Educating for a changing world: The importance of an equity mindset. Met. Univ. 25, 5-15.

Rasooli, A., Zandi, H., and DeLuca, C. (2019). Conceptualising fairness in classroom assessment: exploring the value of Organisational justice theory. Assess. Edu. Princi. Pol. Prac. 26, 584-611. doi: 10.1080/0969594X.2019.1593105

Riordan, M., Klein, E. J., and Gaynor, C. (2019). Teaching for equity and deeper learning: how does professional learning transfer to teachers' practice and influence Students'experiences? Equity Excell. Educ. 52, 327-345. doi: $10.1080 / 10665684.2019 .1647808$

Robeyns, I. (2009). An Introduction to the Human Development and Capability Approach. United States: Routledge.

Scheurich, J. J., Bonds, V. L., Phelps-Moultrie, J. A., Currie, B. J., Crayton, T. A., Elfreich, A. M., et al. (2017). An initial exploration of a community-based framework for educational equity with explicated exemplars. Race Ethn. Educ. 20, 508-526. doi: 10.1080/13613324.2017.1299123

Schreiner, L. A. (2014). Different pathways to thriving among students of color: An untapped opportunity for success. Ab. Camp. Enrich. Stu. Learn. Exp. 19, 10-19. doi: $10.1002 /$ abc. 21169

Shaeffer, S. (2019). Inclusive education: A prerequisite for equity and social justice. Asia Pac. Educ. Rev. 20, 181-192. doi: 10.1007/s12564-019-09598-w

Skerrett, A., Warrington, A., and Williamson, T. (2018). Generative principles for professional learning for equity-oriented urban English teachers. Engl. Educ. 50, 116-146.

Smith, D., Frey, N., Pumpian, I., and Fisher, D. (2017). Building Equity: Policies and Practices to Empower All Learners. United States: ASCD.

Staats, C., Capatosto, K., Wright, R. A., and Jackson, V. W. (2016). State of the Science: Implicit Bias Review. United States: Kirwan Institute.

Stembridge, A. (2019). Culturally Responsive Education in the Classroom. United States: Routledge.

Stoll, S. K. (2011). Social justice: An historical and philosophical perspective. J. Phy. Edu. Rec. Dance. 82, 36-39. doi: 10.1080/07303084.2011.10598675

Sulistyowardani, M., Mambu, J. E., and Pattiwael, A. S. (2020). Indonesian EFL teachers' cognitions and practices related to social justice. Indo. J. App. Ling. 10, 420-433. doi: 10.17509/ijal.v10i2.28614

Sun, Q., and Zhang, L. J. (2021). A sociocultural perspective on English-asa-foreign-language (EFL) Teachers' cognitions about form-focused Iinstruction. Front. Psychol. 12:593172. doi: 10.3389/fpsyg.2021.593172

Villegas, D. (2017). Colombia's Nationwide EFL policy and the construction of equity in policy documents. App. J. App. Lang. Stu. 11, 57-74. doi: 10.17011/apples/urn.201708083437
Von Esch, K. S., Suhanthie, M., and Kubota, R. (2020). Race and language teaching. Lang. Teach. 53, 391-421. doi: 10.1017/S0261444820000269

Wang, D., and Gao, M. (2013). Educational equality or social mobility: The value conflict between Preservice teachers and the free teacher education program in China. Teach. Teach. Educ. 32, 66-74. doi: 10.1016/j.tate.2013.01.008

Wang, Y., and Ryan, J. (2020). The complexity of control shift for learner autonomy: A mixed-method case study of Chinese EFL teachers' practice and cognition. Lang. Teach. Res.:136216882095792. doi: 10.1177/1362168820957922

Wei, W., and Cao, Y. (2020). Written corrective feedback strategies employed by university English lecturers: A teacher cognition perspective. SAGE Open 10:215824402093488. doi: 10.1177/2158244020934886

Woods, D. (1996). Teacher Cognition in Language Teaching: Beliefs, DecisionMaking, and Classroom Practice. United States: Cambridge University Press.

$\mathrm{Wu}, \mathrm{H}$. (2019). Reticence in the EFL classroom: voices from students in a Chinese university. Int. J. App. Ling. Eng. Lit. 8, 114-125. doi: 10.7575/aiac. ijalel.v.8n.6p.114

Wu, X., Zhang, L. J., and Dixon, H. R. (2021). Implementing assessment for learning (AfL) in Chinese university EFL classes: teachers' values and practices. System 101:102589. doi: 10.1016/j.system.2021.102589

Xiang, R., and Yenika-Agbaw, V. (2021). EFL textbooks, culture and power: A critical content analysis of EFL textbooks for ethnic Mongols in China. J. Multiling. Multicult. Dev. 42, 327-341. doi: 10.1080/01434632.2019.1692024

Yao, C. (2021). Is a one-way English immersion teaching approach equitable to Those Chinese non-English major students from rural areas? Educ. Urban Soc.:001312452110275. doi: 10.1177/00131245211027514

Yazan, B., and Rudolph, N. (eds.) (2018). Criticality, Teacher Identity, and (In)equity in English Language Teaching: Issues and Implications. Cham: Springer.

Zhang, Y. W., and Yang, Z. H. (2017). The soft power of Teacher's instructional decision making: An empirical study of 4 Chinese EFL teachers and native English teachers. Eng. Lang. Lit. Stu. 7, 36-44. doi: 10.5539/ells. v7n1p36

Conflict of Interest: The authors declare that the research was conducted in the absence of any commercial or financial relationships that could be construed as a potential conflict of interest.

Publisher's Note: All claims expressed in this article are solely those of the authors and do not necessarily represent those of their affiliated organizations, or those of the publisher, the editors and the reviewers. Any product that may be evaluated in this article, or claim that may be made by its manufacturer, is not guaranteed or endorsed by the publisher.

Copyright (c) 2022 Chen and Abdullah. This is an open-access article distributed under the terms of the Creative Commons Attribution License (CC BY). The use, distribution or reproduction in other forums is permitted, provided the original author(s) and the copyright owner(s) are credited and that the original publication in this journal is cited, in accordance with accepted academic practice. No use, distribution or reproduction is permitted which does not comply with these terms. 